\title{
Fat metabolism during exercise: a review. Part I: fatty acid mobilization and muscle metabolism.
}

Citation for published version (APA):

Jeukendrup, A. E., Saris, W. H. M., \& Wagenmakers, A. J. M. (1998). Fat metabolism during exercise: a review. Part I: fatty acid mobilization and muscle metabolism. International Journal of Sports Medicine, 19(4), 231-244. https://doi.org/10.1055/s-2007-971911

Document status and date:

Published: 01/01/1998

DOI:

10.1055/s-2007-971911

Document Version:

Publisher's PDF, also known as Version of record

\section{Please check the document version of this publication:}

- A submitted manuscript is the version of the article upon submission and before peer-review. There can be important differences between the submitted version and the official published version of record.

People interested in the research are advised to contact the author for the final version of the publication, or visit the DOI to the publisher's website.

- The final author version and the galley proof are versions of the publication after peer review.

- The final published version features the final layout of the paper including the volume, issue and page numbers.

Link to publication

\footnotetext{
General rights rights.

- You may freely distribute the URL identifying the publication in the public portal. please follow below link for the End User Agreement:

www.umlib.nl/taverne-license

Take down policy

If you believe that this document breaches copyright please contact us at:

repository@maastrichtuniversity.nl

providing details and we will investigate your claim.
}

Copyright and moral rights for the publications made accessible in the public portal are retained by the authors and/or other copyright owners and it is a condition of accessing publications that users recognise and abide by the legal requirements associated with these

- Users may download and print one copy of any publication from the public portal for the purpose of private study or research.

- You may not further distribute the material or use it for any profit-making activity or commercial gain

If the publication is distributed under the terms of Article $25 \mathrm{fa}$ of the Dutch Copyright Act, indicated by the "Taverne" license above, 


\title{
Fat Metabolism During Exercise: A Review
}

\author{
Part I: Fatty Acid Mobilization and Muscle Metabolism \\ A. E. Jeukendrup, W. H. M. Saris, A. J. M. Wagenmakers \\ Nutrition Research Center, Department of Human Biology, Maastricht University, Maastricht, The Netherlands
}

A. E. Jeukendrup, W. H. M. Saris, A. J. M. Wagenmakers, Fat Metabolism During Exercise: A Review - Part I: Fatty Acid Mobilization and Muscle Metabolism, Int. J. Sports Med., Vol. 19, pp. $231-244,1998$.

This is the first part in a series of three articles about fat metabolism during exercise. In this part the mobilization of fatty acids and their metabolism will be discussed as well as the possible limiting steps of fat oxidation. It is known for a long time that fatty acids are an important fuel for contracting muscle. After lipolysis, fatty acids from adipose tissue have to be transported through the blood to the muscle. Fatty acids derived from circulating TG may also be used as a fuel but are believed to be less important during exercise. In the muscle the IMTC stores may also provide fatty acids for oxidation after stimulation of hormone sensitive lipase. In the muscle cell, fatty acids will be transported by carrier proteins (FABP), and after activation, fatty acyl CoA have to cross the mitochondrial membrane through the carnitine palmytoyi transferase system, after which the acyl COA will be degraded to acetyl COA for oxidation. The two steps that are most likely to limit fat oxidation are fatty acid mobilization from adipose tissue and transport of fatty acids into the mitochondria along with mitochondrial density and the muscles capacity to oxidize fatty acids.

Key words: Fat metabolism, fatty acids, exercise, FABP, intramuscular triacylglycerols, lipolysis, carnitine, VLDL.

\section{Introduction}

The two main sources of energy for muscle contraction are carbohydrates and fat. Although branched chain amino acids, as well as other amino acids, can also be oxidized in the muscle, their contribution to total energy expenditure is thought to be negligible during aerobic exercise. In the past decade extensive research has been carried out with regard to the role of carbohydrates during exercise, which has led to a quite complete understanding of carbohydrate metabolism under exercising conditions. Far less information is available on the role of fats

Int. J. Sports Med. 19 (1998) $231-244$

o Georg Thieme Verlag Stuttgart $\cdot$ New York during exercise. Hence, our understanding of fat metabolism during exercise is far from complete. The purpose of this review is to give an overview of today's understanding of fat metabolism during exercise. Special attention is given to the factors that limit fat oxidation, the effects of diet on fat metabolism and the effects of training. The review of fat metabolism during exercise will be divided into three separate papers in three subsequent editions of the International journal of Sports Medicine:

Part I Fatty acid mobilization and muscle metabolism Part II Regulation of metabolism and the effects of training

Part III The effects of nutritional interventions on fat metabolism

This part discusses processes of lipolysis, and mobilization of fatty acids, the transport of fatty acids and the uptake and oxidation by the muscle. Reviews addressing these issues in the past include Refs. (55) and (108) and a very recent publication by van der Vusse and Reneman (126).

\section{Nomenclature}

In literature different nomenclature is handled with regard to fatty acids. To avoid misunderstandings or misinterpretations the nomenclature in this review article will be explained. Distinction has to be made between fatty acids which are incorporated into triacylglycerols or other particles, and fatty acids that are not incorporated into triacylglycerols. The fatty acids that are not esterified to form a mono-, di- or triacylglycerol are so called nonesterified fatty acids (NEFAs) or free fatty acids (FFA). The term free fatty acid, might be somewhat ambiguous because, for example in plasma, these fatty acids are bound to albumin and they are not "free". There is also a very small fraction of fatty acids (less than $0.01 \%$ of the plasma fatty acid pool) that is really "free" and not bound to any other compound (non-protein bound fatty acids) $(44,101,102)$. Therefore we will use the term fatty acid (and not free fatty acid) in this review to designate fatty acids that are not esterified to mono-, di-, or triacylglycerois, but might be bound to albumin or fatty acid-binding proteins (FABP). The basic chemical structure of fatty acids is depicted in Fig. 1.

In humans, the chain length of fatty acids typically varies from $\mathrm{C} 14$ to $\mathrm{C} 24$, although fatty acids with shorter or longer chain length may occur (Table 1). Fatty acids with a chain length of 


\begin{tabular}{|c|c|c|c|}
\hline FA & $\begin{array}{l}\text { Double } \\
\text { Bonds }\end{array}$ & Cammon Name & Chemical formula \\
\hline $2: 0$ & - & acetic & $\mathrm{CH}_{3} \mathrm{COO}-$ \\
\hline $4: 0$ & - & butyric & $\mathrm{CH}_{3}\left(\mathrm{CH}_{2}\right)_{2} \mathrm{COO}$ \\
\hline $6: 0$ & - & capronic & $\mathrm{CH}_{3}\left(\mathrm{CH}_{2}\right)_{4} \mathrm{COO}-$ \\
\hline $8: 0$ & - & caprylic & $\mathrm{CH}_{3}\left(\mathrm{CH}_{2}\right)_{6} \mathrm{COO}-$ \\
\hline $10: 0$ & - & caprynic & $\mathrm{CH}_{3}\left(\mathrm{CH}_{2}\right)_{8} \mathrm{COO}-$ \\
\hline $12: 0$ & - & lauric & $\mathrm{CH}_{3}\left(\mathrm{CH}_{2}\right)_{10} \mathrm{COO}$ \\
\hline $14: 0$ & - & myristic & $\mathrm{CH}_{3}\left(\mathrm{CH}_{2}\right)_{12} \mathrm{COO}$ \\
\hline $16: 0$ & - & palmitic & $\mathrm{CH}_{3}\left(\mathrm{CH}_{2}\right)_{14} \mathrm{COO}$ \\
\hline $16: 1$ & $n-6$ & palmitoleic & $\mathrm{CH}_{3}\left(\mathrm{CH}_{2}\right)_{5} \mathrm{CH}=\mathrm{CH}\left(\mathrm{CH}_{2}\right)_{7} \mathrm{COO}-$ \\
\hline $18 ; 0$ & - & stearic & $\mathrm{CH}_{3}\left(\mathrm{CH}_{2}\right)_{16} \mathrm{COO}$ \\
\hline $18: 1$ & $n-9$ & oleic & $\mathrm{CH}_{3}\left(\mathrm{CH}_{2}\right)_{7} \mathrm{CH}=\mathrm{CH}\left(\mathrm{CH}_{2}\right)_{7} \mathrm{COO}$ \\
\hline $18: 2$ & $n-6$ & linoleic & $\mathrm{CH}_{3}\left(\mathrm{CH}_{2}\right)_{4}\left(\mathrm{CH}=\mathrm{CHCH}_{2}\right)_{2}\left(\mathrm{CH}_{2}\right)_{6} \mathrm{COO}-$ \\
\hline $18: 3$ & $n-6$ & $\gamma$-linolenic & $\mathrm{CH}_{3}\left(\mathrm{CH}_{2}\right) 4\left(\mathrm{CH}=\mathrm{CHCH}_{2}\right) 3\left(\mathrm{CH}_{2}\right)_{3} \mathrm{COO}-$ \\
\hline $18: 3$ & $n-3$ & $\alpha$-linolenic & $\mathrm{CH}_{3}\left(\mathrm{CH}_{2}\right)\left(\mathrm{CH}=\mathrm{CHCH}_{2}\right)_{3}\left(\mathrm{CH}_{2}\right)_{6} \mathrm{COO}-$ \\
\hline $20: 0$ & - & arachidonic & $\mathrm{CH}_{3}\left(\mathrm{CH}_{2}\right)_{18} \mathrm{COO}$ \\
\hline $20: 2$ & $n-6$ & eicosadinoic & $\mathrm{CH}_{3}\left(\mathrm{CH}_{2}\right)_{4}\left(\mathrm{CH}=\mathrm{CHCH}_{2}\right)_{2}\left(\mathrm{CH}_{2}\right)_{8} \mathrm{COO}-$ \\
\hline $20: 3$ & $n-6$ & eicosatrinoic & $\mathrm{CH}_{3}\left(\mathrm{CH}_{2}\right)_{4}\left(\mathrm{CH}=\mathrm{CHCH}_{2}\right)_{3}\left(\mathrm{CH}_{2}\right)_{5} \mathrm{COO}-$ \\
\hline $20: 4$ & $n-6$ & arachidonic & $\mathrm{CH}_{3}\left(\mathrm{CH}_{2}\right)_{4}\left(\mathrm{CH}=\mathrm{CHCH}_{2}\right)_{4}\left(\mathrm{CH}_{2}\right)_{2} \mathrm{COO}-$ \\
\hline $20: 5$ & $n-3$ & eicosapentaenoic (EPA) & $\mathrm{CH}_{3}\left(\mathrm{CH}_{2}\right)\left(\mathrm{CH}=\mathrm{CHCH}_{2}\right)_{5}\left(\mathrm{CH}_{2}\right)_{2} \mathrm{COO}-$ \\
\hline $22: 0$ & - & behenic & $\mathrm{CH}_{3}\left(\mathrm{CH}_{2}\right)_{20} \mathrm{COO}$ \\
\hline $22: 5$ & $n-3$ & docosapentaenoic & $\mathrm{CH}_{3}\left(\mathrm{CH}_{2}\right)\left(\mathrm{CH}=\mathrm{CHCH}_{2}\right)_{5}\left(\mathrm{CH}_{2}\right)_{4} \mathrm{COO}-$ \\
\hline $22: 6$ & $n-3$ & docosahexaenoic (DHA) & $\mathrm{CH}_{3}\left(\mathrm{CH}_{2}\right)\left(\mathrm{CH}=\mathrm{CHCH}_{2}\right)_{6}\left(\mathrm{CH}_{2}\right) \mathrm{COO}-$ \\
\hline $24: 0$ & - & lignoceratic & $\mathrm{CH}_{3}\left(\mathrm{CH}_{2}\right)_{22} \mathrm{COO}$ \\
\hline
\end{tabular}

Table 1 Nomenclature and formulas of fatty acids (FA)
C8 or $\mathrm{C} 10$ are called medium chain fatty acids (MCFAs) whereas those with a chain length of $C 6$ or less are called short chain fatty acids (SCFAs) (67). The most abundant fatty acids are the long chain fatty acids (LCFAs) with a chain length of C12 or more. Of the long chain fatty acids palmitic acid (C16) and oleic acid ( $\mathrm{C} 18$, one double bond) are the most abundant. Fatty acids with no double bonds in their hydrocarbon chain are called saturated fatty acids and those with one or more double bonds unsaturated fatty acids. Fatty acids with one double bond are referred to as monounsaturated fatty acids whereas fatty acids with two or more double bonds are called polyunsaturated fatty acids. Also the position of the double bond is usually indicated. For example $\mathrm{C} 20: 4(n-3)$ means that this 20 carbon fatty acid with 4 double bonds has the first double bond starting from the third carbon counting from the terminal methyl group (Fig. 1). Another way of indicating the fatty acid and the position of the double bond is $C 20: 4 \omega 3$.

Oxidizable lipid fueis include fatty acids, intramuscular triacylglycerols (IMTG) and circulating plasma triacylglycerols (TG; chylomicrons and very low density lipoproteins (VLDL)). These plasma TG are usually incorporated in lipoproteins like chylomicrons, very low density lipoproteins (VLDL), low density lipoproteins (LDL), intermediate density lipoproteins (IDL) or high-density lipoproteins (HDL). These lipoproteins differ in their density, TG content, cholesterol content but they also fulfill different functions. VLDL for instance is the main lipoprotein species for transport of triacylglycerols from the liver to adipose tissue and muscle while HDL is transporting cholesterol from the peripheral tissues to the liver. Therefore it is believed that chylomicrons and VLDL may play a role in energy a $M M^{\mathrm{cooh}}$
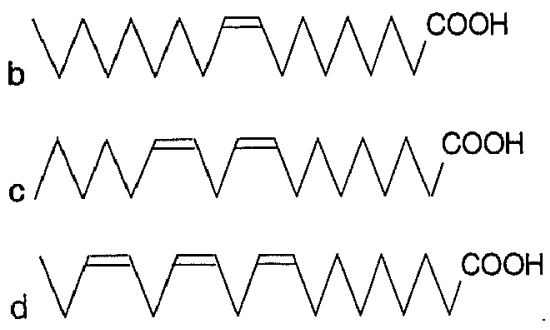

Fig. 1 Chemica! structure of some common fatty acids. a stearic acid, $18: 0$ b oleic acid, $18: 1$ (n-9); c linoleic acid $18: 2(n-6) ; \mathbf{d} \alpha$-linolenic acid $18: 3(n-3)$ metabolism during exercise while LDL, IDL and HDL probably do not play a significant role in the energy provision for the muscle. Also fat derived compounds such as ketone bodies (acetoacetate and $\beta$-hydroxybutyrate) can serve as a fuel whereas glycerol can be converted into glucose in gluconeogenesis in the liver and subsequently be oxidized as glucose.

\section{Fatty Acids Versus Carbohydrates}

Fatty acids have several biochemical and physical properties which distinguish them from carbohydrates and, in many cases, make them the substrate of choice. One of these properties is that fat contains more than twice as much energy per gram than carbohydrates, $38 \mathrm{~kJ} \cdot \mathrm{g}^{-1}\left(9 \mathrm{kcal} \cdot \mathrm{g}^{-1}\right)$ for fats versus $18 \mathrm{~kJ} \cdot \mathrm{g}^{-1}\left(4 \mathrm{kcal} \cdot \mathrm{g}^{-1}\right)$ for carbohydrates. Furthermore, carbohydrates are stored in the presence of water, whereas fat is stored almost anhydrous ( $1 \mathrm{~g}$ of glycogen binds about $2 \mathrm{~g}$ of 
water [63]). This makes fat a far more efficient fuel per unit of weight. If all the fat in our body would be replaced by an equienergetic amount of carbohydrates our weight would double. Fat appears to be the ideal fuel for long lasting exercise in situations in which the provision of food is limited. A good example to illustrate this are certain animal species, like migratory birds, who fly for days without eating. These birds who rely heavily on their endogenous energy stores, store almost exclusively fat as a fuel (43).

In humans, both fat and carbohydrate is stored. Carbohydrates are stored as glycogen in muscle and liver. Muscle glycogen can be used directly to fuel contractile processes while glucose from liver glycogen first has to be transported by the blood, and taken up by the muscle before it can be oxidized. Gluconeogenic substrates such as lactate, glycerol and amino acids can be converted into glucose in the liver and can indirectly serve as an energy substrate. In addition, exogenous carbohydrate sources can also provide glucose for oxidative processes in the muscle after they are absorbed in the gut and have entered the circulation. The carbohydrate stores are small. The total amount of muscle glycogen of an $80 \mathrm{~kg}$ man is about 400 grams (Table 2 ) although trained individuals may have larger glycogen stores. Liver glycogen represents about 80-100 grams. The total amount of plasma substrates (glucose and lactate) is about 20 grams. Expressed in terms of energy, the body carbohydrate stores represent approximately $8000 \mathrm{~kJ}$ $(2000 \mathrm{kcal})$. In comparison with this, fat stores are very large and theoretically the fat store could provide energy for days whereas the glycogen stores can become depleted within $60-$ $90 \mathrm{~min}$. It has been estimated that running a marathon which requires about $83 \mathrm{~kJ} / \mathrm{min}$ ( $21 \mathrm{kcal} / \mathrm{min}$ ) for elite marathon runners while non-elite runners expend a similar amount of energy over the entire distance $(42.2 \mathrm{~km}$; about $12000 \mathrm{~kJ})(92)$. So it can be calculated that 500 grams of glycogen can fuel about 95 min of running at marathon pace to elite runners. Calculating the amount of energy stored as fat for an $80 \mathrm{~kg}$ man and $60 \mathrm{~kg}$ woman (average body composition) this would provide respectively $450000 \mathrm{~kJ}(110000 \mathrm{kcal})$ and $550000 \mathrm{~kJ}$ (135000 kcal). Energy stored in the form of carbohydrates can vary in a range from $6000 \mathrm{~kJ}(1500 \mathrm{kcal})$ to $12000 \mathrm{~kJ}$ ( $3000 \mathrm{kcal})$. In other words, if only fat or only carbohydrates could be utilized as a fuel, the carbohydrate stores from exercising muscles would deliver energy for no more than 95 min of marathon running while energy derived from fat stores

Table 2 The energy stores of an $80 \mathrm{~kg}$ man

\begin{tabular}{lllr}
\hline Substrate & & $\begin{array}{l}\text { Weight } \\
(\mathrm{kg})\end{array}$ & \multicolumn{1}{c}{$\begin{array}{l}\text { Energy } \\
(\mathrm{kJ})\end{array}$} \\
\hline carbohydrates & plasma glucose & 0.02 & 320 \\
& liver glycogen & 0.1 & 1600 \\
& muscle glycogen & 0.4 & 6400 \\
fat & total (approximately) & 0.52 & 8000 \\
& plasma fatty acid & 0.0004 & 16 \\
& plasma triacylglycerols & 0.004 & 160 \\
& adipose tissue & 12 & 404000 \\
& intramuscular triacylglycerols & 0.3 & 10800 \\
& total (approximately) & 12.3 & 440000
\end{tabular}

The values given are estimates for a "normal" man of $80 \mathrm{~kg}$. The amount of protein in the body is not mentioned but this would be about $10 \mathrm{~kg}(160000 \mathrm{~kJ})$ mainly located in the muscle. would be satistactory for 119 hours of continuous marathon running (92).

Of course adipose tissue contains the largest quantity of fat, and most of the fat in man is stored in subcutaneous and deep visceral adipose tissue. The storage of fat is dynamic, which means that in case of a negative energy balance, the size of the individual fat cells will decrease whereas with a positive balance, the excess of fatty acids will be converted into triacylglycerols and hypertrophy of fat cells will result. Although adipose tissue is by far the most important site of storage, fat is also stored within the muscle. The size of this fat pool is difficult to determine, but is estimated to be between 7 and $40 \mathrm{mmol} \cdot \mathrm{kg} \mathrm{ww}^{-1}(14,35,40,70,109)$. The total amount of fat stored in all muscle cells has been estimated to be approximately 300 grams (10), but assuming a muscle mass of $18 \mathrm{~kg}$ in a $80 \mathrm{~kg}$ man, and TG concentrations in the muscle in the range of 7 to $40 \mathrm{mmol} \cdot \mathrm{kg} \mathrm{ww}^{-1}$ this may vary from $100-600$ grams. The amount of fatty acids stored váries substantially between tissues but also within tissues. In muscle tissue for instance, type 1 fibers have been shown to have a higher TG content than type II fibers $(35,39)$. Besides these TG stores in adipose tissue and muscle there is a small fraction of fatty acids in the blood, transported by lipoproteins or as a fatty acid, bound to albumin.

Fatty acids provide more ATP per molecule than glucose does. A glucose molecule can produce 38 ATP whereas a molecule of stearic acid can produce 147 ATP. However, to produce the same amount of ATP, oxidation of fatty acids requires more oxygen than the oxidation of carbohydrates (88). The oxidation of one molecule glucose requires 6 molecules of oxygen while, for example, the complete oxidation of stearic acid requires 26 molecules of oxygen.

Furthermore, per unit of time more ATP can be derived from carbohydrates (glucose) than from the oxidation of fatty acids (88). When blood-borne fatty acids are oxidized the maximum rate of high energy phosphate (HEP) formation is $\sim 0.40 \mathrm{~mol}$ HEP - min $^{-1}$ while the aerobic or anaerobic breakdown of endogenous glycogen can generate $\sim 1.0-2.4 \mathrm{~mol} \mathrm{HEP} \cdot \mathrm{min}^{-1}(126)$. Because metabolic pathways beyond the formation of acetyl$\mathrm{COA}$ are identical for carbohydrate and fatty acid oxidation, the rate-limiting step in overall fat utilization must be proximal to the tricarboxylic acid (TCA)-cycle (possibly $\beta$-oxidation, activation of the fatty acid, carnitine mediated transport across the mitochondria or transport of fatty acids from the blood to the intracellular site of activation). At present the question as to which part of overall fatty acid utilization is rate limiting is yet unsolved. The possible limiting steps will be discussed below.

\section{Fat as a Fuel During Exercise}

In the early years, Zuntz $(145,146)$, Krogh and Lindhardt (80) and later Christensen and Hansen (24) showed that a mixture of carbohydrates and fat are used as a fuel at rest and during exercise. Based on the fact that carbohydrates produce different amounts of $\mathrm{CO}_{2}$, and require different amounts of $\mathrm{O}_{2}$ when they are oxidized, they used $\mathrm{VO}_{2}$ and $\mathrm{VCO}_{2}$ measurements in expiratory gases to obtain information about substrate utilization. The ratio $\mathrm{VCO}_{2} / \mathrm{VO}_{2}$ in expired air, the respiratory exchange ratio ( $\mathrm{R}$ ) will be $0.69-0.73$ when only fat is oxidized 
(depending on the length of the carbon chain of the fatty acid oxidized) and will be 1.0 when only glucose is oxidized. These early studies showed not only that both carbohydrate and fat were used during exercise but also that their relative contribution changed dependent on the exercise intensity, the exercise duration, and the diet prior to exercise $(24,32,80)$. In general over $50 \%$ of the energy requirements at rest is derived from fatty acid oxidation (50). Fatty acids remain a very important substrate during exercise, as long as the exercise intensity is below $80-90 \% \mathrm{VO}_{2} \max (47,50,105)$. Above this exercise intensity carbohydrates are the predominant substrate $(1,47,50$, 105).

While early studies were mainly based on respiratory gas exchange measurements, after World War II radioactive and stable isotope tracers became available and with tracer dilution techniques it was possible to investigate the kinetics of substrate mobilization and utilization (97). Very important was also the reintroduction of the muscle biopsy technique by Bergström and Hultman $(8,9,69)$ in the late sixties. These techniques made it possible to quantify substrate fluxes and measure tissue substrate concentrations.

\section{Processes that Potentially Limit Fat Oxidation}

Since body glycogen stores are relatively small and it has been shown that depletion of these stores results in fatigue, it would be beneficial for performance if at the same exercise intensity more fatty acids could be oxidized and less carbohydrates. However, even though the fat stores are relatively large, the capacity to oxidize fatty acids is limited and in many cases carbohydrates are the dominant substrate. The reason for this limitation in the use of fat stores is still not fully elucidated. The limitations in fat oxidation might be located at different levels: 1. Mobilization of fatty acids from adipose tissue

2. The transport of fatty acids to the muscle

3. The uptake of fatty acids by the muscle cell

a. The uptake of plasma fatty acids

b. The uptake of fatty acids from circulating plasma lipoprotein-TG

4. Mobilization of fatty acids from IMTG pools

5. The transport of fatty acids into the mitochondria

6 . The oxidation of fatty acids in the mitochondria

\section{Mobilization of fatty acids}

Most tissues (i.e. muscle, liver, intestine, brain) contain only small amounts of fat and the ability of these tissues for de novo synthesis of fats is small in comparison to the fatty acid turnover during exercise. Therefore most tissues depend on a continuous supply of fatty acids from the diet and from adipose tissue. This also holds for muscle. The rate of mobilization of fatty acids from adipose tissue is dependent on 1 . the rate of $1 \mathrm{i}-$ polysis, 2 . the rate of reesterification of fatty acids within the adipocyte and 3 . the transport rate of fatty acids from adipose tissue to the blood.

\section{Lipolysis in adipose tissue}

In adipose tissue, fatty acids are constantly mobilized by lipolysis (hydrolysis of triacylglycerols), a process that can be initiated by the sympathetic nervous system (SNS). A first step in the process of lipid mobilization from adipocytes is the trans-

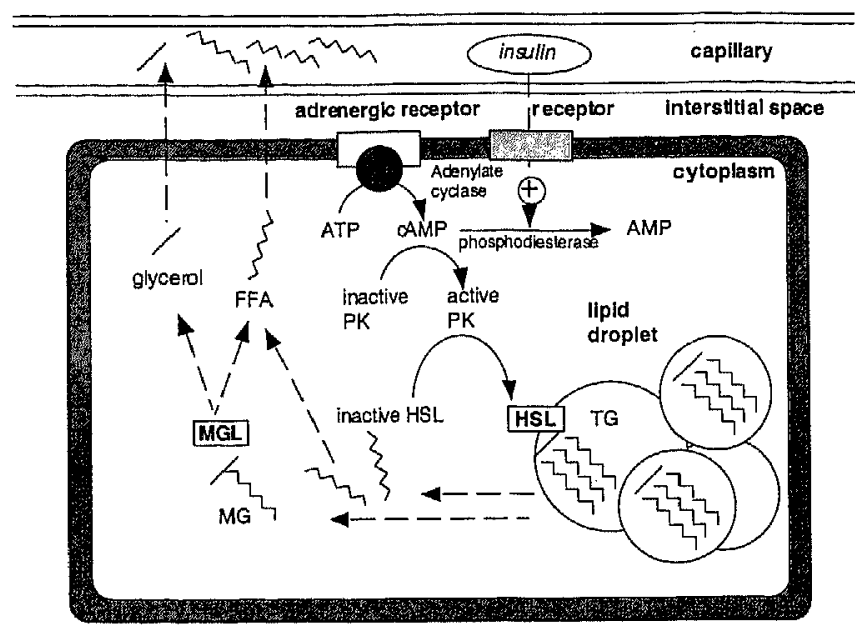

Fig. 2 Mobilization of fatty acids from adipose tissue. Triacylglycerols are transported from the lipid droplet to the cytoplasm of the adipocyte. This triacylglycerol is subjected to cleavage by the enzyme hormone-sensitive lipase (HSL); a monoacylglycerol is formed and two fatty acids which can diffuse into the circulation. The remaining monoacylglycerol is split by the enzyme monoacylglycerol lipase (MGL) into glycerol and another fatty which can also diffuse into the circulation. The rate limiting step in the mobilization of fatty acids from the lipid droplet is HSL. This enzyme is present in an active and an inactive form and can be activated by adrenergic stimulation, which will trigger a cascade of events leading to phosphorylation of the inactive hormone sensitive lipase. Insulin will stimulate phosphodiesterase leading to decreased CAMP levels and decreased activation of HSL. (PK = protein kinase, $H S L=$ hormone sensitive lipase, $T G=$ triacylglycerol, fatty acid $=$ free fatty acids).

fer of triacylglycerols from the main lipid droplet to the site of enzymatic cleavage in the cytoplasm of the adipocyte (Fig. 2). Although there is only little information about this process, it is believed not to be rate-limiting (11). A second step in the mobilization of fatty acids is the enzymatic cleavage of the triacylglycerol in the cytoplasm. The fatty acids in the outer or $\beta$-position of the triacylglycerols are hydrolyzed by the action of hormone sensitive lipase (HSL). This enzyme is subjected to hormonal regulation. The remaining monoacylglycerol (glycerol with a fatty acid in the $\alpha$-(inner) position) is then hydrolyzed by the more active enzyme monoacylglycerol lipase.

Glycerol cannot be reutilized by the adipocyte to form new triacylglycerols since the enzyme glycerol kinase, is only present in very low concentrations or even absent in adipose tissue (and muscle) (104). Glycerol is a small water soluble molecule which can easily diffuse through the cell membrane into the blood. Therefore all the glycerol produced by lipolysis in the adipocyte is released into the circulation. For this reason glycerol appearance in the blood is often used as a measurement of (whole-body) lipolysis. However, it must be noted that in certain conditions such as ischaemia, there may also be other sources of glycerol production (i.e. hydrolysis of glycerol-3-phosphate into glycerol) as shown by de Groot et al (29) for heart muscle. Furthermore, Elia et al. (33) raise the possibility that glycerol released from IMTG might be directly oxidized, which may result in an underestimation of tracer determined whole-body lipolysis. Unlike glycerol, fatty acids can be reesterified to form new triacylglycerols, a process called triacylglycerol-fatty acid cycling. Tracer studies generally as- 
sume that some of the fatty acids and all of the glycerol formed by lipolysis in the cytoplasm will diffuse out of the adipocyte into the circulation.

The rate of lipolysis is largely dependent on the activation of hormone sensitive lipase. The regulation of the activity of this enzyme is of primary importance for the mobilization of fatty acids from adipose tissue. The activity of the enzyme is dependent on several inhibitory and stimulatory factors. The SNS and circulating epinephrine concentrations appear to be the major stimulatory factors (41) and insulin is probably the main counterregulatory hormone (58). Studies in isolated human adipocytes have revealed that at physiological concentrations, catecholamines, glucocorticoids, thyroid stimulating hormone and growth hormone are good stimulators of lipolysis $(26,58)$. The relative importance of these stimulating factors on lipolysis is not fully elucidated. On the contrary, lactate (53) ketone bodies (26) and especially insulin (58) have an inhibitory effect on the enzyme.

The transfer of SNS activity to the cellular level occurs through adrenergic receptors. In human adipose tissue, catecholamines have both $\alpha$-adrenergic inhibitory and $\beta$-adrenergic stimulatory effects on the rate of lipolysis $(26,37)$. Through the adrenergic receptors a cascade of events is triggered: the adenylate cyclase system is activated which activates the protein kinase system. The protein kinase, in its turn, will activate the lipase by phosphorylation. Insulin acts mainly by stimulating phosphodiesterases which break cAMP down to AMP, thereby preventing the stimulation of HSL. On the other hand, caffeine, for instance, is a known stimulator of the adenylate cyclase system, and therefore also a potent stimulator of lipolysis (see section on caffeine, part III, Effects of nutritional interventions).

Studies using microdialysis have shown that in man, $\alpha$-adrenergic inhibitory mechanisms modulate lipolysis at rest, whereas $\beta$-adrenergic stimulatory effects are predominant during exercise (5).

During exercise the plasma insulin concentration will decrease, mainly due to the inhibiting effect of epinephrine and to a lesser extent norepinephrine upon pancreatic insulin release. Because insulin is a strong inhibitor of lipolysis, the net effect will be an increased lipolysis. At the same time the sensitivity of $\beta$-adrenergic receptors for catecholamines will increase in adipose tissue (133). The combination of these effects results in an increased lipolysis in adipose tissue during low to moderate intensity exercise. At high exercise intensities ( $>80 \%$ $\mathrm{VO}_{2} \max$ ), high circulating levels of epinephrine, in combination with increased glycolytic flux, increased plasma lactate concentrations may reduce lipolysis and increase reesterification in adipose tissue resulting in a decreased Ra fatty acids.

\section{Removal rate of fatty acids from adipose tissue}

Although the major regulatory factors controlling adipose tissue fatty acid mobilization are through adrenergic stimulation and insulin, the rate at which fatty acids are removed from the adipose tissue appears to be another factor. The removal rate of fatty acids from the adipose tissue is dependent on the plasma albumin concentration, the arterial fatty acid/albumin ratio and the blood flow through adipose tissue (17). The plasma al- bumin concentration in plasma is fairly constant (about $0.6 \mathrm{mmol} \cdot \mathrm{l}^{-1}$ ) while in most conditions (except for prolonged fasting and long lasting endurance exercise) the fatty acid concentration varies between $0.2-1.0 \mathrm{mmol} \cdot \mathrm{l}^{-1}$. During moderate intensity exercise arterial plasma fatty acid concentrations may increase up to twenty-fold. This leads to changes in the fatty acid/albumin ratio from a resting value of 0.2 to values of 3-4 during exercise. Since albumin binds fatty acids with decreasing affinity when more binding sides are occupied (113), increases in the fatty acid/albumin ratio are accompanied by increased concentrations of the non-protein bound fatty acid fraction in plasma. This in turn favours reesterification within the adipocyte since the fatty acid/albumin ratio in plasma is increased even more $(15,20)$. It has also been shown that adipose tissue blood flow markedly increases the removal rate from adipose tissue and thus the mobilization of fatty acids $(17,20)$. Madsen et al. (83) showed that in perfused adipose tissue increases in the fatty acid/albumin ratio as well as decreases in the adipose tissue blood flow decreased fatty acid mobilization. They suggested that the decreased net fatty acid output was due to increased rates of reesterification or a decreased transport capacity of the blood. During exercise blood flow through adipose tissue may increase up to three-fold which may partly compensate for the decreased transport capacity caused by the increased plasma fatty acid/albumin ratio $(16,18,19)$.

\section{Triacylglycerol-fatty acid cycling}

As mentioned before, glycerol which is liberated after lipolysis, cannot be incorporated into triacylglycerols since the enzyme glycerol kinase is virtually absent in adipose tissue and muscle (104). In adipose tissue this enzyme is needed to convert glycerol to glycerol-3-phosphate (G-3-P), which is the backbone of a triacylglycerol molecule. Therefore the rate of appearance (Ra) of glycerol is often used as a direct index of lipolysis (141). The G-3-P required for reesterification is indirectly derived from glucose in the adipose tissue. Formation of G-3-P involves the reduction of dihydroxyacetone phosphate, a glycolytic intermediate. The newly formed G-3-P can then be bound to acyl-CoA to synthesize triacylglycerols. With low blood glucose levels, less G-3-P will be formed and consequently the rate of fatty acid reesterification will decrease $(142,143)$. The excess fatty acids will be released into the circulation. This TG hydrolysis and subsequent reesterification was the first documented substrate cycle and is called the triacylglycerol-fatty acid cycle (Fig. 3 ). The functioning of this cycle allows the adipocyte to adjust the release of fatty acids rapidly in response to alterations in metabolic demands. For instance, when there is not enough glucose available, reesterification will be decreased and more fatty acids will be mobilized from the adipose tissue (142). Reesterification may occur within the adipocyte (intracellular reesterification) or fatty acids may be released and reesterified in some other tissue (extracellular reesterification).

Assuming complete hydrolysis of each TG molecule, the release of 1 molecule glycerol should be accompanied by the release of 3 molecules fatty acids, if no reesterification occurs after hydrolysis of triacylglycerols. However, the release ratio between glycerol (Ra glycerol) and fatty acids (Ra FA) is usually found to be 1-2 (142). This means that part of the fatty acids derived from lipolysis will not enter the blood stream but will 


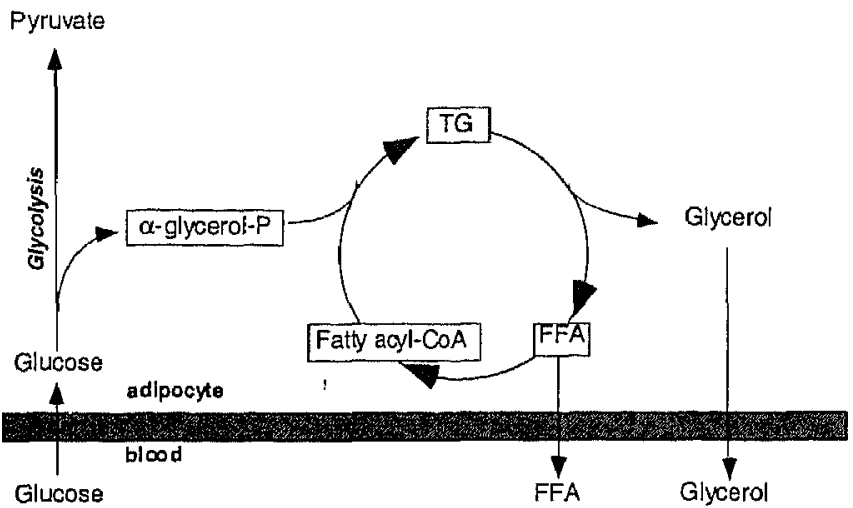

Fig. 3 The triacylglycerol-fatty acid cycle. Fatty acids (FA) mobilized after hydrolysis of triacylglycerols (TG) can either be released into the circulation or reesterified with a molecule of glycerol-3-phosphate (G$3-P)$. This TG hydrolysis and subsequent reesterification is called the triacylglycerol-fatty acid cycle.

be used for reesterification. Stimulation of lipolysis takes place very rapidly after the onset of exercise (5). However, the rate of lipolysis is far in excess of the need for fatty acids in oxidative processes. Therefore it was concluded that fatty acid mobilization was regulated by reesterification. During the first $30 \mathrm{~min}$ of exercise at $40 \% \mathrm{VO}_{2} \max _{1}$ the reesterification of fatty acids was markedly decreased. Whereas at rest approximately $70 \%$ of all released fatty acids were reesterified, during exercise only $25 \%$ was reesterified (142). Similar findings were obtained by Hodgetts et al. (62) during exercise at 50-70\% $\mathrm{VO}_{2} \mathrm{max}$. During the first $30 \mathrm{~min}$ of exercise, reesterification is suppressed and at the same time lipolysis is increased and adipose tissue blood flow is increased (16). This results in a massive increase in rate of appearance and availability of fatty acids in the plasma. The rate of reesterification is also dependent on the ability of plasma to carry away released fatty acids (i.e. the number of free albumin binding sites for fatty acids and the adipose tissue blood flow), and the availability of glucose to produce G-3-P. In addition, lactate has been shown to increase the rate of fatty acid reesterification $(73,98,111)$. Shaw et al. (111) stated that a lactate concentration of $2 \mathrm{mmol} \cdot 1^{-1}$ reduces fatty acid output by $35-40 \%$ in the whole animal.

\section{Transport of lipids by the blood}

When fatty acids have passed the cell membrane of the adipocyte either passively or mediated by membrane associated proteins such as fatty acid translocase (FAT) or fatty acid-transport protein (FATP) $(60,110,126)$, they will move through the interstitium bound to albumin, pass the vascular wall of the capillaries and again bind to the circulating albumin. Since albumin has at least three high-affinity fatty acid binding sites (113), under physiological circumstances a minority of all binding sites are occupied. The largest fraction of fatty acids in the plasma (more than $99.9 \%$ ) are carried bound to albumin $(101,102)$. Prior to extraction by skeletal muscle, fatty acids have to be released from albumin since the permeability of endothelial cells, lining the wall of muscle capillaries, is very low for the albumin-fatty acid complex (7). As discussed above, blood flow and the saturation of the albumin-fatty acid complex appear to be important factors in the mobilization of fatty acids from adipose tissue (21). In the liver fatty acids can be incorporated in lipoproteins (very low density lipoproteins VLDL). Also other lipoproteins function as carriers for fatty acids through the blood (chylomicrons, low density-lipoprotein [LDL], high-density lipoprotein [HDL]).

\section{Mechanism of uptake of fatty acids}

Havel et al. (61) showed in 1967 that during exercise plasma fatty acid concentrations increased along with the fatty acid uptake although the fractional extraction rate decreased. Studies in men and dogs have suggested that a linear relationship exists between fatty acid concentration in the blood and the utilization of fatty acids, suggesting that the uptake of fatty acids by the muscle is a passive process that occurs by passive diffusion $(4,71)$. However, this traditional view has recently been challenged $(7,125)$. Evidence is accumulating indicating the existence of a "carrier system" for fatty acids across the cell membrane. Although the details of the transport of fatty acid into the muscle cell are largely unknown, it is generally accepted that one or more membrane-associated proteins are involved $(22,99,129)$. Carrier proteins such as FAT and FATP with fatty acid-transport stimulating properties have been identified in adipocytes (60). Recently, FABPpm $(22)$, FAT $(2,45)$, and $\operatorname{FATP}(2,45)$ have also been identified in skeletal muscle.

Besides protein mediated transport, part of the fatty acids will passively pass the cellular membranes because of the lipophilic nature of the fatty acids $(45,126)$.

The initial step in the uptake of fatty acids from the plasma would be the translocation through the luminal membrane of the endothelial cell, the cytoplasmic compartment of the endothelial cell and subsequently through the albuminal membrane of the endothelial cell (Fig. 4). Next, the fatty acids have to be transported through the interstitial space most probably bound to albumin (125). Then the fatty acids will be transported through the sarcolemma, either by passive diffusion or facilitated by plasma membrane bound FABP (FABPpm) (125) or as recently suggested by proteins in the membrane: FAT and FATP $(45,129)$. In the cytoplasm, fatty acids are bound to cytoplasmic FABP (FABPC) and transport of the fatty acids within the cytoplasm occurs bound to this protein $(45,46,129)$. Vork et al. (130) reported a significant positive correlation between the percentage of muscle FABP content and the percentage of oxidative fibers in skeletal muscle, suggesting that FABP plays an important role in the rate of fatty acid oxidation.

Although the mechanism of fatty acid transport into the muscle cell is largely unknown, the existence of a carrier mediated transport might explain the findings of Turcotte et al. (124) and Kiens et al. (77). In isolated perfused rat skeletal muscle (124) and in man (77), it was observed that the uptake of non-protein bound fatty acids by the muscle followed saturation kinetics and did not increase linearly with the increasing fatty acid concentration in the blood as was generally believed. Above a certain fatty acid concentration, saturation of the transport process occurred, which could indicate a limitation in the transport over the cell membrane although limitations distal from the fatty acid uptake cannot be excluded (i.e. oxidation). The data implying saturation kinetics of fatty acid uptake are derived from plots of fatty acid uptake against the delivered non-protein bound fatty acid fraction $(51,77,112,118$, 


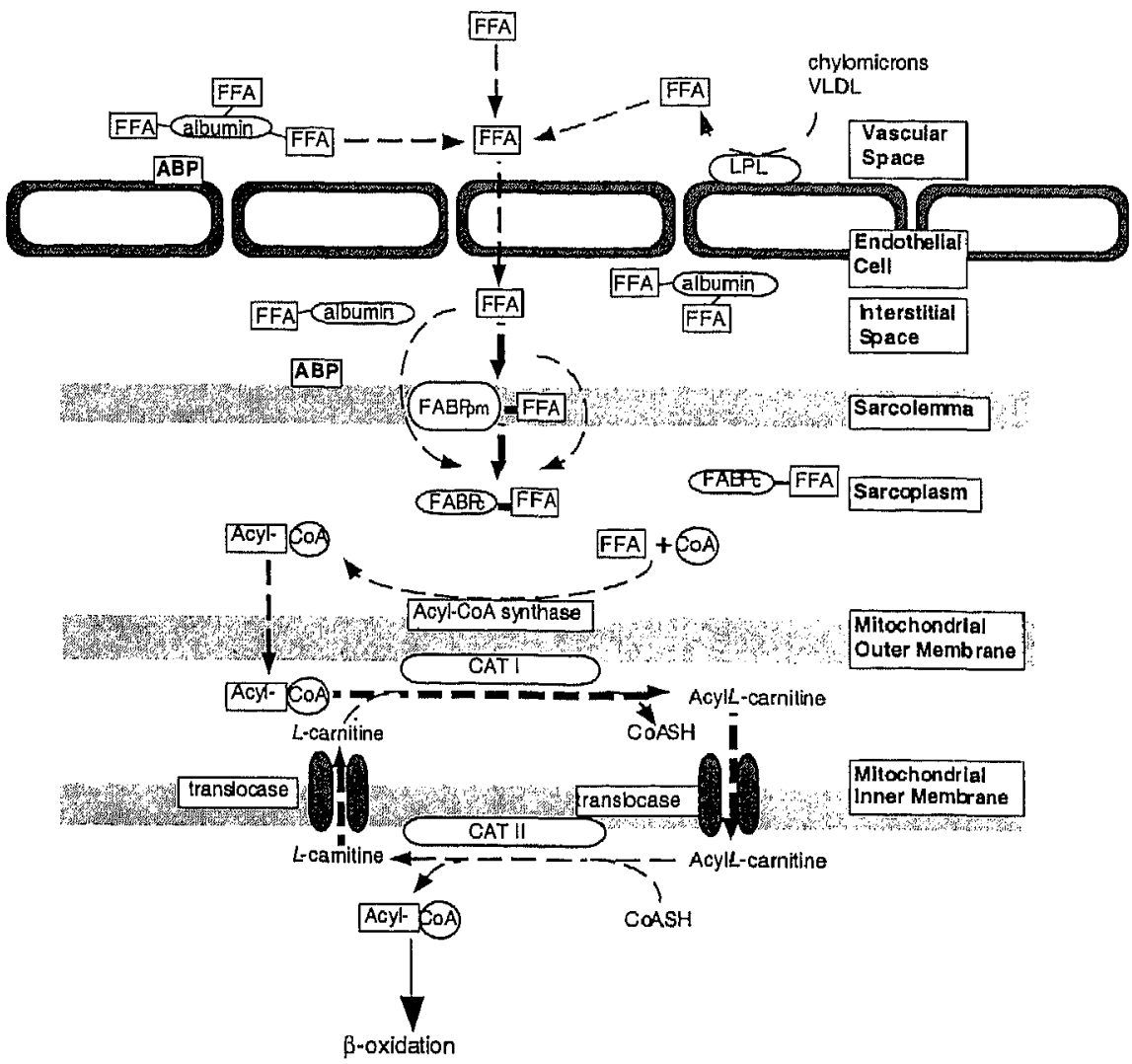

Fig. 4 Transport of fatty acids from the vascular space into the mitochondria of the muscle cell. Fatty acids in plasma are bound to albumin and after transport into the interstitial space again bound to albumin. Fatty acid cross the sarcolemma by a plasma membrane bound "fatty acid-binding protein $\left(F A B P_{\text {pin }}\right)$ and in the sarcoplasm they will be bound to a cytoplasmic fatty acid-binding protein $\left(F A B P_{c}\right)$. Subsequently fatty acid will be activated by acyl-CoA synthetase to form a acyl-CoA which can be transported via carnitine palmytol transferase I (CPT I), a translocase and carnitine palmytoyl transferase II (CPT II) into the mitochondrial matrix. This transport into the mitochondria is carnitine dependent. Acyl-CoA units inside the mitochondrial matrix may be subjected to enzymatic cleavage in the $\beta$-oxidation.

124). Recently it has been suggested that although the largest fraction of fatty acids in plasma (99.9\%) are carried bound to albumin, fatty acid uptake may be dependent on the small non-protein bound fatty acid fraction in the plasma $(0.1 \%$ of the total fatty acid pool in plasma) $(77,124)$.

\section{Availability of plasma fatty acids}

Because fat is stored mainly outside the muscle cell in adipose tissue, availability of fatty acid as a substrate is dependent on lipolysis in adipose tissue, transport through the blood and fatty acid uptake by the muscle. However lipolysis in the muscle may be another very important factor determining fatty acid availability especially in endurance trained humans. During the first minutes of exercise plasma fatty acid concentration decreases as a result of a delay between the increased uptake of fatty acid directly after the onset of exercise and the stimulation of lipolysis (23). Once lipolysis is fully activated and reesterification is suppressed, the plasma fatty acid concentration will rise (142). Plasma fatty acid concentration increases progressively with increasing submaximal exercise intensity $(48,49,92)$. At high exercise intensities ( $\left.>80 \% \mathrm{VO}_{2} \max \right)$, however, fatty acid availability may be limited as a result of decreased fatty acid ( $R a$ fatty acid) release from adipose tissue (105).

At cessation of exercise the utilization of fatty acid is drastically reduced whereas the lipolytic activity will be maintained because of the metabolic activation. As a result fatty acid levels in the blood will increase in the postexercise period (92). After $10-15$ min a peak fatty acid concentration is reached, and concentrations will decline again to resting levels $(0.2-0.5 \mathrm{mmol}$. $\left.1^{-1}\right)$. After exercise, and sometimes even during exercise, fatty acid concentrations may increase up to $2 \mathrm{mmol} \cdot \mathrm{l}^{-1}$. It is generally assumed that fatty acid concentrations above $2 \mathrm{mmol} \cdot \mathrm{I}^{-1}$ are toxic in humans $(74,92)$. High post-exercise fatty acid concentrations can also be regarded in a positive way, since they replenish muscle TG stores (134). Hagenfeldt et al. (57) showed that fatty acid oxidation is in large part dependent on the plasma fatty acid concentration. However, the rate of fatty acid oxidation in the working muscle is not only determined by the plasma fatty acid concentration, but factors like the number and the size of mitochondria (see part II, the effects of training on plasma fatty acid utilization), and probably also the presence of other substrates such as glucose determines the rate at which fatty acids can be oxidized. Coyle et al. (27) showed that the reduced oxidation of long chain fatty acids during exercise when hyperglycemic and hyperinsulinemic was partly due to a reduction in the availability of plasma fatty acids and partly due to other factors located inside the muscle cell. Horowitz et al. (68) showed that pre-exercise glucose ingestion resulted in decreased fatty acid oxidation. This effect was partly caused by an insulin induced reduction in lipolysis and a reduction in plasma fatty acid concentration. However, when plasma fatty acid levels were restored to the same level as during the control trial (no pre-exercise glucose feeding) by infusing a triacylglycerol emulsion plus heparin, fat oxidation was only partially restored. These findings indicate that fatty acid concentration may be an important factor but it is not the only factor determining plasma fatty acid oxidation.

In other studies it has been shown that higher rates of glycogenolysis and subsequent glycolysis which lead to higher muscle pyruvate concentrations at high exercise intensities (107, 
114) are accompanied by lower rates of fat oxidation. Apart from a reduction of the rate of fatty acid oxidation by high muscle pyruvate concentrations (either through activation of $\mathrm{PDH}$ (glucose-fatty acid cycle) or through malonyl-CoA; see discussion in part II), there are also suggestions that high rates of fatty acid oxidation can only be maintained in the presence of a minimal amount of TCA cycle intermediates (TCAI) (107, 127,128 ). In the absence of carbohydrates, the fatty acid oxidation is inhibited in isolated perfused hindlimb from the rat $(103,123)$. It has been shown clearly that the concentration of TCAl in skeletal muscle increases severalfold, rapidly after the start of exercise (107). The alanine aminotransferase reaction in muscle (pyruvate + glutamate $\leftrightarrow$ alanine $+\alpha$-ketoglutarate) seems to function to achieve this increase and maintain high concentrations of TCAI during prolonged exercise $(107,127$, 128 ). The increase in muscle pyruvate thereby is the driving force to shift the alanine aminotransferase reaction (equilibrium reaction) to the right towards synthesis of $\alpha$-ketoglutarate and the other TCAI. However, an adequate anaplerotic rate cannot be maintained when muscle glycogen becomes depleted during prolonged exercise and muscle pyruvate concentrations start to fall. This implies that the maximal TCA cycle flux will be reduced once muscle glycogen has been depleted and fatty acids have become the main substrate. Decreased fatty acid oxidation in the absence of carbohydrates $(103,123)$ may therefore be in agreement with the theory that glycogen depletion leads to fatigue because the number of TCA-cycle intermediates decreases below a critical level $(107,127)$. This may explain why endurance athletes during competition have to reduce the exercise intensity to about $50 \% \mathrm{VO}_{2} \max$ when glycogen stores have become depleted and fatty acids have become the main fuel.

\section{Uptake of fatty acids from circulating lipoproteins}

Another potential source of fatty acids is triacylglycerols bound to lipoproteins (VLDL and chylomicrons) (61). Muscular endothelium is virtually impermeable for circulating lipoproteins. Before fatty acid can be taken up by the muscle, they have to be released from the triacylglycerols forming the core of the lipoproteins (VLDL and chylomicrons). Only after hydrolysis of the lipoprotein-TG by lipoprotein lipase (LPL), can fatty acid be transported into the muscle cell. LPL is located on the luminal surface of the vascular wall (13) and will hydrolyze some of the TG in the lipoproteins passing through the capillary bed. LPL activity is found in most, if not all, tissues. The highest activities have been reported in cardiac and red skeletal muscle and adjpose tissue. The response of LPL activity to certain stimuli (like fasting or exercise) appears to be tissue specific (81). For example during fasting or exercise the LPL activity is increased in heart and skeletal muscle whereas at the same time the LPL activity in adipose tissue is reduced (81).

Attempts have been made, using arteriovenous balances and radioactive labelled TG, to quantify the plasma TG oxidation. From most of these studies, contribution of fatty acids derived from plasma TG to the total fat metabolism during exercise appears to be very small $(59,61,95,96)$. Attempts to quantify VLDL-TG utilization during exercise have revealed that the fatty acid uptake from plasma lipoprotein triacylglycerols occurs slowly (144) and accounts for less than $5 \%$ of the fatty-acid derived $\mathrm{CO}_{2}$ during prolonged exercise $(61,72)$. Therefore it is often believed that plasma TG contribute only minimally to en- ergy production during exercise $(61,72,144)$. However, there are some interesting observations that need further investigation. For instance LPL activity is significantly increased after training (79) and after a high-fat diet (78), both situations in which fat oxidation is markedly increased. In addition, acute exercise also stimulates muscle LPL activity (121). Furthermore, studies in exercising dogs showed that the contribution of VLDL-TG is not negligible (122). These findings together suggest that TG from plasma lipoproteins may be an important fuel during exercise even though attempts to measure the contribution of plasma TG directly report that plasma TG are not a major fuel during exercise. Therefore the contribution of VLDL$T G$ (and chylomicron-TG) to energy expenditure remains uncertain.

\section{Muscle triacylglycerols}

Muscle triacylglycerols are stored in depots, mostly adjacent to the mitochondria (66) (Fig. 5).

Skeletal muscle contains on average about $12 \mathrm{mmol} \cdot \mathrm{kg}^{-1} \mathrm{wW}$ TG $(14,35,52,70,109)$ but this can vary markedly because of factors such as fiber type, nutrition and physical exercise. Histological studies revealed that Type I fibers contain more TG than Type Ila fibers in humans. Type IIb fibers displayed the lowest concentration of intramuscular TG (35). Glycolytic fibers rely less on TG as a source of energy and as a consequence TG pools can be smaller in these fibers. As will be discussed below, it is sometimes hard to distinguish between intramuscular triacylglycerol and intermuscular triacylglycerol (i.e. triacylglycerol from adipocytes which are interlaced between muscle fibers). Little is known about the role of inter-versus intramuscular triacylglycerol stores. However, the fact that trained subjects have more intramuscular and less intermuscular triacylglycerols (66) while they oxidize more muscle triacylglycerols (84) suggests that the intramuscular triacylglycerol stores are the most important in terms of energy provision.

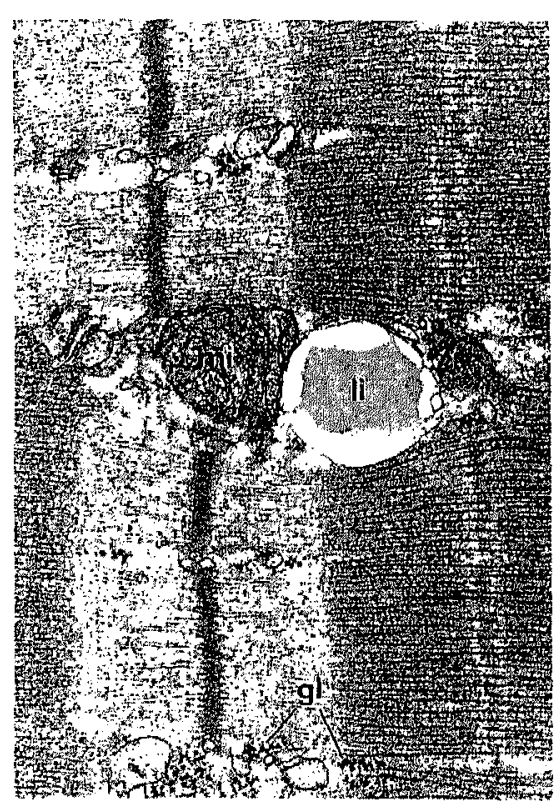

Fig. 5 Electron microscopy image of a lipid droplet (ii) in close proximity to the mitochondria (mi) of skeletal muscle. Also visible are the intramuscular glycogen $(\mathrm{Hgl})$ granules. Micrograph Courtesy: H. Claassen, Institute of Anatomy, University of Bern, Switzerland. 
Although triacylglycerol metabolism in adipose tissue has been thoroughly described over the years, our knowledge about the regulation of muscle TG metabolism is very limited. Surprisingly, not even the enzyme responsible for the hydrolysis of TG has been identified. In rat skeletal muscle three different triacylglycerol lipases (TGL) have been found, each with distinct activities at a pH of $5.0,7.0$ or 8.5. These lipases are known as acid, neutral and alkaline lipase, respectively. The alkaline lipase was identified as lipoprotein lipase (119). It has been suggested that this alkaline TGL (LPL) in muscle serves mainly to catalyze the cleavage of fatty acids from circulating TG. The neutral TGL, which is most likely under hormonal control, and influenced by the adrenergic system, may be the enzyme responsible tor the intramuscular lipolysis (52). However; the information on this enzyme in skeletal muscle is scarce. The regulation of the intramuscular lipases has been studied indirectly. When norepinephrine was infused, a significant reduction in the IMTG content was observed in humans (40). Also, stimulation of $\beta$-adrenergic receptors in rat diaphragm with isoproterenol increased in vitro lipolysis and this increase was partially prevented by the addition of insulin to the incubation medium (3). Furthermore, propanolol administration to swimming rats was found to prevent a decline in muscle triacylglycerol, indicating that $\beta$-adrenoceptor blockade effectively inhibits intramuscular neutral lipid degradation during exercise (116). In isolated perfused heart it was shown that with epinephrine, the glycerol release was increased (137). Furthermore, by perfusion with dibutyryl adenosine 3',5'-cyclic monophosphate (cAMP), TG decreased by $50 \%$ in perfused rat hearts (42). This may indicate that, as in adipose tissue, cardiac lipolysis is mediated at least in part, through the classical cAMP cascade. Cleroux et al. (25) showed that muscle triacylglycerol lipolysis is mediated by $\beta 2$-adrenoceptors. In subjects performing prolonged exercise until exhaustion, muscle triacylglycerol utilization was completely blocked by nadolol, a non-selective $\beta$-blocker, whereas it was unchanged with atenolol, a selective $\beta 1$-adrenoceptor blocker. Indirect support for these observations in skeletal muscle comes from studies showing that muscle triacylglycerol lipolysis occurs mainly in slow-twitch fibers $(115,117)$ which also have a higher density of $\beta 2$-adrenoceptors (136). Because results inclicated that extramuscular lipolysis decreased to the same extent with $\beta 1$-adrenoceptoror $\beta 1+\beta 2$-adrenoceptorblockade it was concludied that adipose tissue lipolysis is only partially controlled by the adrenergic system and mainly through $\beta 1$-adrenoceptors, whereas skeletal muscle triacylglycerol breakdown appears to be controlled by the adrenergic system through $\beta 2$-adrenoceptors (25). However, at present it is still not completely clear to what extent $\beta 1, \beta 2$ and $\beta 3$-adrenoceptors are involved in skeletal muscle lipolysis. There is also evidence that lipolysis in muscle and IMTG degradation can be influenced by direct stimulation of the sciatic nerve (115) or after direct stimulation of a muscle with electrodes (65), indicating that other factors than adrenergic stimulation (i.e., local mechanisms) may play a role in regulating intramuscular lipolysis. Gorski et al. (52) hypothesized that $\mathrm{Ca}^{2+}$ may be a likely candidate for exerting a local stimulating effect on endogenous TG lipases.

Early studies using ${ }^{14} \mathrm{C}$-labelled fatty acids to quantify fatty acid turnover indicated that muscle TG were used during exercise $(56,61)$. These studies revealed that during submaximal exercise $(60-120 \mathrm{~min})$, plasma fatty acid contributed only
$50 \%$ to total fat oxidation, implicating that the residue must have come from other fat sources, most likely intramuscular triacylglycerols. With electron microscopy, fat vacuoles in the muscle were studied before and after exercise (94). The size of the vacuoles was smaller after exercise suggesting that indeed fatty acids were mobilized from these vacuoles and subsequently oxidized (94). Studies using muscle biopsies indicated that muscle TG content decreases during exercise $(14,36,39$, 100). However, other studies were not able to find differences between pre- and post-exercise TG content in muscle biopsies $(48,75)$. Part of the inconsistent results can be explained by the muscle biopsy technique applied. The muscle biopsy, usually $50-150 \mathrm{mg}$ wet weight, represents only a smal part of the whole muscle and might not be representative for the whole muscle TG stores. TG are not stored homogeneously over the muscle compartments and as noted above, different fiber types have different TG contents (109). Especially in human muscle biopsies this may be a problem since pre- and post-exercise muscle biopsies usually have a slightly different fiber type composition. Wendling et al. (135) recently showed that TG measured in repeated muscle biopsies displayed a large variation resulting in coefficients of variation between 20 $26 \%$. They suggest that only changes in IMTG larger than $24 \%$ may be detectable. In addition to accurately quantify intramuscular triacylglycerol utilization, it is of utmost importance that all surrounding fat is carefully dissected from the muscle fibers before the triacylglycerol content is analyzed. If this dissection is not performed, the measured triacylglycerol content will be the sum of intramuscular triacylglycerols and adipocytes located between muscle fibers. Recently MR spectroscopy techniques were used to quantify intramuscular triacylglycerol concentrations in vivo (12). These techniques may enable more precise measurements of intramuscular triacylglycerol concentrations in the future. Boesch et al. (12) reported a 6\% error in their method. However, they also reported considelable differences between individuals when the same muscle was investigated.

It was estimated that the contribution of muscle TG to total energy expenditure during exercise $\left(65 \% \mathrm{VO}_{2} \mathrm{max}\right)$ was $15-35 \%$ $(70,75)$. It must be noted, however, that this contribution was calculated by subtracting plasma fatty acid uptake from total fat oxidation and the difference theoretically reflects TG in the muscle, TG between muscle fibers and TG in VLDL. In this study it was assumed that the contribution of VLDL-TG was negligible. Romijn et al. (105) investigated the energetic contribution of different substrates during exercise at three different exercise intensities. The contribution of intramuscular TG was $7 \%, 26 \%$ and $8 \%$ during exercise at $25 \%, 65 \%$ and $85 \%$ of $\mathrm{VO}_{2} \mathrm{max}$, respectively (Fig. 6). This suggests that there is an optimum in intramuscular TG utilization somewhere between $25 \%$ and $85 \% \mathrm{VO}_{2} \max$. Endurance trained athletes rely more on their IMTG. Martin et al. (84) showed that training increased the contribution of IMTG utilization to total energy expenditure. This will be discussed in more detail in part II of this review, section "The effect of training on IMTG utilization".

In general it can be concluded that muscle TG are utilized during submaximal exercise, and they are an important substrate for the contracting muscle. Unfortunately, methodological problems make quantification of intlamuscular triacylglycerol utilization very difficult. 


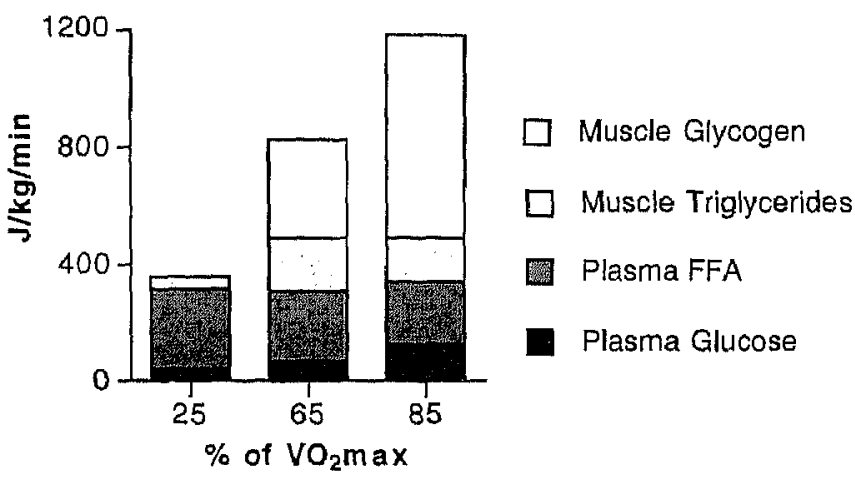

Fig.6 Substrate utilization at different exercise intensities (25\% $\mathrm{VO}_{2} \max , 65 \% \mathrm{VO}_{2}$ max and $80 \% \mathrm{VO}_{2}$ max). Data adapted from Romijn et al. (105).

\section{Transport of fatty acids across the mitochondrial membrane}

Once fatty acids enter the cytoplasm of the muscle cell they can either be esterified and stored into intracellular TC (28) or the fatty acid can be bound to the FABP for transport to the site of oxidation and activated to a fatty acyl-CoA by the enzyme acyl-CoA synthetase. The activation of the fatty acid is an extramitochondrial process. The mitochondrial inner membrane is impermeable for acyl-CoA (or fatty acid) so that a carrier is needed for translocation of the activated fatty acid over the mitochondrial inner membrane. First the acyl-CoA ester is converted into acyl-carnitine by carnitine acyl transferase (CAT I) located at the outer face of the inner mitochondrial membrane and reconverted into fatty acyl-CoA at the matrix side of the inner mitochondrial membrane by the enzyme CAT II (Fig. 4). Acyl carnitine crosses the inner membrane in a $1: 1$ exchange with a molecule free carnitine, a transport step which is controlled by the protein acyl carnitine translocase $(93,126)$. It is generally believed that medium-and short chain fatty acids can more freely diffuse into the mitochondrial matrix, where they are converted to their respective CoA esters. However, at least part of these fatty acids are transported by specific carrier proteins short- or medium chain acyl-CoA transferases $(54,106)$. Because malonyl-CoA, an intermediate of biosynthesis of fatty acids, inhibits CAT I this is believed to be involved in the regulation of overall fat utilization $(27,85-$ $87,106,138-140$ ). The possible role of malonyl-CoA in the regulation of fatty acid oxidation will be discussed in part II of this review, section "Regulation through malonyl-CoA".

The importance of the carnitine-acyl-transport system across the inner mitochondrial membrane becomes obvious when regarding the serious complications observed in carnitine-deficient patients (120). These patients are unable to use fat as a fuel. Consequently, they rely heavily on their glycogen stores, which will become depleted earlier during exercise. Early fatigue and decreased performance will result.

There is preliminary indirect evidence suggesting that the carnitine dependent transport of long chain fatty acids into the mitochondria may be a rate limiting step in the process of fatty acid oxidation. When intravenous infusions of long chain fatty acids are given (which are dependent on the carnitine transport system to cross the inner mitochondrial membrane), lower oxidation rates are found compared to medium chain fatty acids which are less dependent on this carnitine transport system $(27,89)$. However, at present it is uncertain to what extent the carnitine dependent transport of fatty acid into the mitochondria is rate limiting.

\section{Oxidation of fatty acids}

In the $\beta$-oxidation, the fatty acyl-CoA is stepwise degraded to acetyl-CoA and an acyl-CoA residue, shortened by two carbons. The acetyl-CoA units can enter the tricarboxylic acid cycle (TCA-cycle) and follow the exact same pathway as acetylCoA units from pyruvate. The shortened fatty acyl-CoA acts again as a substrate for the $\beta$-oxidative pathway until it is completely oxidized. The rate at which fatty acids are oxidized depends on the type of fatty acids. Fatty acyl moieties that are poorly oxidized by the mitochondria (i.e. very long chain fatty acids) may be oxidized (126). Both the number of carbon atoms and the degree of saturation have been shown to influence the oxidation rate. It is known that medium chain fatty acids (MCFA) are more rapidly and more completely oxidized than long chain fatty acids (LCFA) (6). Jones et al. (76) studied whole body oxidation rates of fatty acids with a similar chain length (C 18) but different degrees of saturation. Remarkable differences in the oxidation rates were observed: oleic acid (C18:1 n-9) was more rapidly oxidized than linoleic acid (C18:2 n-6) which in turn was more rapidly oxidized than stearic acid ( $\mathrm{C} 18: 0)$. In vivo studies in rats (82) showed that the oxidation rates of fatty acids decreased with increasing chain length $(C 12: 0>C 14: 0>C 16: 0>C 18: 0)$. There were considerable differences in the oxidation rates of different unsaturated fatty acids (C18:3n-3>C18:1 n-3>C18:3n-6> $C 22: 6 n-3>C 20: 4 n-6)$. Oleic acid ( $C 18: 1)$ was oxidized at a remarkably high rate, almost as fast as lauric acid (C12:0). Of the $n-6$ fatty acids linoleic acid ( $C 18: 2 n-6)$ was oxidized at a faster rate than any of its metabolites, with arachidonic acid (C20:4n-6) being oxidized at the lowest rate. The rate of oxidation of $\alpha$-linolenic acid ( $C 18: 3 n-3)$ was almost as fast as lauric ( $C 12: 0)$ and oleic acid (C18:1 n-9). In incubated hepatocyte cultures, rates of fatty acid uptake and ketone body formation were of the order $C 16: 1>C 16: 0>C 18: 2>C 18: 1>$ C18:0 (34). Hagenfeldt and Wahren (56) also observed a slight preferential extraction of linoleic $(C 18: 2 n-6)$ and oleic acid (C18:1) compared to palmitic acid (C16:0) across the forearm. From these studies it appears that saturated and unsaturated fatty acids are oxidized at different rates.

\section{Other fat metabolites}

Other fat related compounds such as glycerol and ketone bodies can also serve as a fuel during exercise. Glycerol is released after hydrolysis of TG and will be transported to the vascular space. Via the blood glycerol will be transported to the liver where it can serve as a gluconeogenic precursor for glucose, However, studies with glycerol administration showed that the conversion rate of glycerol to glucose was inadequate to contribute significantly to the energy expenditure during exercise $(90,91)$. 
The ketone bodies (acetoacetate and $\beta$-hydroxybutyrate) are products of incomplete fatty acid oxidation. Under normal circumstances, the liver is the only organ with the ability to produce ketone bodies. On the other hand ketone bodies can be oxidized by most tissues including skeletal muscle. The concentration of ketone bodies in the plasma is usually very low $\left(50-150 \mathrm{mmol} \cdot \mathrm{l}^{-1}\right)$ but may increase markedly after fasting or during prolonged exercise $(14,30,31)$. During fasting, the production of ketone bodies is extremely important since they serve as an alternative fuel for glucose in the brain. Glucose and ketone bodies are the only fuels that can be utilized by the brain. Normally there is ample glucose to provide the brain with energy substrates. However, during fasting the availability of glucose is markedly reduced and ketone bodies can serve as an alternative fuel in muscle cells. With respect to energy provision during exercise, the contribution of ketone bodies is generally believed to be negligible $(38,92)$.

\section{Summary and Concluding Remarks}

Fatty acids are an important fuel for contracting muscle. After lipolysis, fatty acids from adipose tissue have to be transported through the blood to the muscle. Fatty acids derived from circulating TG may also be used as a fuel but are believed to be less important during exercise. In the muscle the IMTG stores may also provide fatty acids for oxidation after stimulation of hormone sensitive lipase. In the muscle cell, fatty acids will be transported by carrier proteins (FABP), and after activation fatty acyl $C O A$ have to cross the mitochondrial membrane through the carnitine palmytoyl transferase system, after which the acyl CoA will be degraded to acetyl CoA for oxidation.

The two steps that are most likely to limit fat oxidation are fatty acid mobilization from adipose tissue and transport of fatty acicls into the mitochondria along with mitochondrial density and the muscles capacity to oxidize fatty acids.

In part II of this review we will focus on the interaction between carbohydrate and fat metabolism and the regulation of fatty acid metabolism. Also the effects of training will be discussed.

In part III of this review the effects of various nutritional manipulations will be discussed.

\section{Acknowledgment}

We greatly acknowledge the help of Dr. Hans Hoppeler (University of Bern, Switzerland) who provided the excellent micrograph in Fig. 5.

\section{References}

1. Abernethy PJ, Thayer R, Tayler AW. Acute and chronic responses of skeletal muscle to enclurance and sprint exercise. Sports Med 1990; 10: $365-89$

2. Abumrad NA, El-Maghrabi MR, Amri E-Z, Lopez E, Grimaldi PA. Cloning of a fat adipocyte membrane protein implicated in binding or transport of long-chain fatty acids that is induced during preadipocyte differentiation. J Biol Chem 1993; 268: $17665-8$

3. Abumrad NA, Stearns SB, Tepperman HM, Tepperman J. Studies on serum lipids, insulin and glucogen and on muscle triglyceride in rats adapted to high-fat and high-carbohydrate diet.J Lipid Res 1978; 19: 423-32

4. Armstrong DT, Steele R, Altszuler N, Dunn A, Bishop JS, De Bodo RC. Regulation of plasma free fatty acid turnover. Am J Physiol $1961 ; 201: 9-15$

5. Arner P, Kriegholm E, Engfeldt P, Bolinder J. Adrenergic regulation of lipolysis in situ at rest and during exercise. J Clin Invest 1990; 85: 893-8

6. Bach AC, Babayan VK. Medium-chain triglycerides: an update. Am J Clin Nutr 1982; 36: 950-62

7. Bassingthwaighte JB, Noodleman L, van der Vusse G, Glatz JFC. Modeling of palmitate transport in the heart. Mol Cell Biochem 1989; 88: $51-8$

8. Bergstrom J, Hermansen L, Hultman E, Saltin B. Diet, muscle glycogen and physical performance. Acta Physiol Scand 1967; 71: $140-50$

9. Bergstrom J, Hultman E. Muscle glycogen synthesis after exercise: an enhancing factor localized in muscle cells in man. Nature 1966; $210: 309-10$

10. Bjorkman 0 . Fuel utilization during exercise. Biochemical aspects of physical exercise. Amsterdam: Elsevier, 1986: 245-60

11. Björntorp P. Adipose tissue adaptation to exercise. Exercise, fitness and health. Champaign, Illinois: Human Kinetics books. 1990: $315-23$

12. Boesch C, Slotboom J, Hoppeler H, Kreis R. In vivo determination of intra-myocellular lipids in human skeletal muscle by means of localized ${ }^{1} \mathrm{H}-\mathrm{MR}-$ spectroscopy. Magn Res Med 1997; 37: 484-93

13. Braun JEA, Severson DL. Regulation of the synthesis, processing and translocation of lipoprotein lipase. Bioch J 1992; 287: 337 47

14. Brouns F, Saris WHM, Beckers E, Adlercreutz $H$, van der Vusse GJ, Keizer HA, Kuipers $H$, Menheere P. Wagenmakers AJM, ten Hoor $F$. Metabolic changes induced by sustained exhaustive cycling and diet manipulation. Int J Sports Med 1989; 10: S49-S62

15. Bülow J. Subcutaneous adipose tissue blood flow and triacylglycerol-mobilization during prolonged exercise in dogs. Pfluglers Arch 1982; 392: 230-4

16. Bülow J. Adipose tissue blood flow during exercise. Dan Med Bull 1983; 30: $85-100$

17. Bülow J. Regulation of lipid mobilization in exercise. Can J Sport Sci 1987; 12: 117 S-119 S

18. Bülow J, Madsen J. Adipose tissue blood flow during prolonged heavy exercise. Pfluglers Arch 1976; 363: 231 -4

19. Bülow J, Madisen J. Adipose tissue blood flow during prolonged heavy exercise II. Pfluglers Arch 1978; 378: $41-5$

20. Bülow J, Madsen J, Astrup A, Christensen NJ. Vasoconstrictor effect of high FFA/albumin ratios in adipose tissue in vivo. Acta Physiol Scand 1985; 125: $661-7$

21. Bülow J, Simonsen L, Madsen J. Effect of exercise and glucose ingestion on adipose tissue metabolism. Integration of Medical and Sport Sciences. Basel: Karger, 1992: 329-35 
22. Calles-Escandon J, Sweet $L_{1}$ Ljungqvist $O$, Hirshman MF. The membrane associated $40 \mathrm{kD}$ fatty acid binding protein (Berk's protein), a putative fatty acid transporter, is present in skeletal muscle. Life Sci 1996; 58: $19-28$

23. Carlson LA, Pernow B. Studies on blood lipids during exercise. II. The arterial plasma-free fatty acid concentration during and after exercise and its regulation. J Lab Clin Med 1961; 58: 673 81

24. Christensen EH, Hansen 0 . Arbeitsfähigkeit und Ernährung. Scand Arch Physiol 1939; 81: 160-71

25. Cleroux I, van Nguyen P, Taylor AW, Leenen FHH. Effects of $\beta 1$ vs. $\beta 1+\beta 2$-blockade on exercise endurance and muscle metabolism in humans. J Appl Physiol 1989; 66: 548-54

26. Coppack SW, Jensen MD, Miles JN. In vivo regulation of lipolysis in humans. J Lipid Res 1994; 35: 177-93

27. Coyle EF, Jeukendrup AE, Wagenmakers AJM, Saris WHM. Fatty acid oxidation is directly regulated by carbohydrate metabolism during exercise. Am J Physiol 1997; 273: in press

28. Dagenais GR, Tancredi RG, Zierler KL. Free fatty acid oxidation by forearm muscle in rest, and evidence for an intramuscular lipid pool in the human forearm. J Glin Invest 1976; 58:421 - 31

29. de Groot MJM, de Jong Y, Coumans WA, van der Vusse G]. The hydrolysis of glycerol-3-phosphate into glycerol in cardiac tissue: possible consequences for the validity of glycerol release as a measure of lipolysis. Pfluglers Arch 1994; 427: 96-101

30. Dohm GL, Beeker RT, Israel RG, Tapscott EB. Metabolic responses after fasting. J Appl Physiol 1986; 61: 1363-8

31. Dohm GL, Tapscott EB, Barakat HA, Kasperek GJ. Influence of fasting on glycogen depletion in rats during exercise. J Appl Physiol 1983; 55: 830-3

32. Edwards HT, Margaria R, Dill DB. Metabolic rate, blood sugar and the utilization of carbohydrate. Am J Physiol 1934; 108: $203-9$

33. Elia M, Khan $K$, Calder $G$, Kurpad A. Glycerol exchange across the human forearm assessed by a combination of tracer and arteriovenous exchange techniques. Clin Sci 1993; 84: $99-104$

34. Emmison N, Agius L. Fatty acid uptake and metabolism to ketone bodies and tricylglycerol in rat and human hepatocyte cultures is dependent on chain length and degree of saturation. FEBS 1988; 236: $83-8$

35. Essen B. Intramuscular substrate utilization during prolonged exercise. Ann N Y Acad Sci, New York Academy of Sciences. 1977: $30-44$

36. Essen-Gustavsson B, Tesch PA. Glycogen and triglyceride utilization in relation to muscle metabolic characteristics in men performing heavy-resistance exercise. Eur J Appl Physiol 1990; 61: $5-10$

37. Fain JN, Garciá-Sáinz JA. Adrenergic stimulation of adipocyte metabolism. J Lipid Res 1983; 24: 945-66

38. Felig $P$, Wahren J. Fuel homeostasis in exercise. New Eng J Med 1975; 20: $1078-1975$

39. Fröberg SO. Effect of acute exercise on tissue lipids in rats. Metabolism 1971; 20:714-20

40. Fröberg SO, Hultman E, Nilsson LH. Effect of noradrenaline on triglyceride and glycogen concentrations in liver and muscle from man. Metabolism 1975; 24: 119-26

41. Galster AD, Clutter WE, Cryer PE, Collins JA. Epinephrine plasma thresholds for lipolystic effects in man. J Clin Invest 1981; 67: $1729-38$

42. Gartner $S L_{t}$ Vahouny GV. Effects of epinephrine and 3',5'-AMP on perfursed rat hearts. Am J Physiol 1972; 222: $1121-4$

43. George JC, Jyoti D. Histological features of the breast and leg muscles of bird and bat and their physiological and evolutionary significance. 1955: $31-6$

44. Glatz JFC, van der Vusse GJ. Lipid terminology: "free fatty acid is ambiguous". TIBS 1988; 13: 167-77
45. Glatz JFC,van der Vusse GJ. Cellular fatty acid binding proteins: their function and physiological significance. Progress in Lipid Research, 1996: in press

46. Glatz JFC, van der Vusse GJ, Veerkamp JH. Fatty acid binding proteins and their physiological significance. NIPS 1988; 3: $41-3$

47. Gollnick PD. Metabolism of substrates: energy substrate metabolism during exercise and as modified by training. Fed Proc 1985: 44: 353-7

48. Gollnick PD, lanuzzo CD, Williams $C$, Hill TR. Effect of prolonged, severe exercise on the ultrastructure of human skeletal muscle. Int Z Angew Physiol 1969; 27: 257-65

49. Gollnick PD, Pernow B, Essen B, Jansson E, Saltin B. Availability of glycogen and plasma FFA for substrate utilization in leg muscle of man during exercise. Clin Physiol 1981; 1: 27-42

50. Gollnick PD, Saltin B. Fuel for muscular exercise. Exercise, nutrition and energy metabolism. New York: Macmillan Publishing Company, 1988: $71-88$

51. Goresky CA, Daly DS, Mishkin S, Arias IM. Uptake of labelled palmitate by the intact liver: role of intracellular binding sites. Am J Physiol 1978; 3: E542 -E553

52. Gorski J. Muscle triglyceride metabolism during exercise. Can J Physiol Pharmacol 1990; 70: 123-31

53. Green HJ, Houston ME, Thomson JA, Sutton JR, Gollnick PD. Metabolic consequences of supramaximal arm work performed during prolonged submaximal leg work. J Appl Physiol 1979; 46: $249-55$

54. Groot PHE, Hülsmann WC. The activation and oxidation of octanoate and palmitate by rat skeletal muscle mitochondria. Biochim Biophys Acta 1973; 316: 124-35

55. Guezennec CY. Role of lipids on endurance capacity in man. Int J Sports Med 1992; 13: S114-S118

56. Hagenfeldt L, Wahren J. Human forearm muscle metabolism during exercise II. Scand J Clin Lab Invest 1968; 21: $263-76$

57. Hagenfeldt $L_{1}$ Wahren J. Metabolism of free fatty acids and ketone bodies in skeletal muscle. Muscle metabolism during exercise, II. New York: Plenum, 1971: 153-63

58. Hales CN, Luzio JP, Siddle K. Hormonal control of adipose-tissue lipolysis. Bioch Soc Symp 1978; 43: $97-135$

59. Hargreaves M, Kiens B, Richter EA. Effect of increased plasma free fatty acid concentrations on muscle metabolism in exercising men.J Appl Physiol 1991; 70: 194-201

60. Harmon CM, Abumrad NA. Binding of sulfosuccinimidyl fatty acids to adipocyte membrane proteins: isolation and aminoterminal sequence of an 88-kD protein implicated in transport of long-chain fatty acids. J Membr Biol 1993; 133: 43-7

61. Havel RJ, Pernow B, Jones NL. Uptake and release of free fatty acids and other metabolites in the legs of exercising men.J Appl Physiol 1967; 23: 90-9

62. Hodgetts V, Coppack SW, Frayn KN, Hockaday TDR. Factors controlling fat mobilization from human subcutaneous adipose tissue during exercise. J Appl Physiol 1991; 71: 445-51

63. Holloszy JO. Utilization of fatty acids during exercise. Exerc Sport Sci Rev. Illinois: Hum Kin Publ, 1988: 319-27

64. Holloszy JO, Coyle EF. Adaptations of skeletal muscle to endurance exercise and their metabolic consequences. J Appl Physiol $1984 ; 56: 831-8$

65. Hopp JF, Palmer WK. Effect of electrical stimulation on intracelIular triacylglycerol in isolated skeletal muscle. J Appl Physiol 1990; 68: $348-54$

66. Hoppeler H. Exercise-induced ultrastructural changes in skeletal muscle. Int J Sports Med 1986; 7: 187-204

67. Hornstra G. Dietary fats, prostanoids and arterial thrombosis. The Hague: Martinus Nijhoff publishers, 1982

68. Horowitz JF, Mora-Rodriguez R, Byerley LO, Coyle EF. Lipolytic suppression following carbohydrate ingestion limits fat oxidation during exercise. APStracts 1997; 4: $0145 \mathrm{E}$ 
69. Hultman E. Physiological role of muscle glycogen in man, with special reference to exercise. Circ Res 1967; 10:1-99-1 - 114

70. Hurley BF, Nemeth PM, Martin WH III, Hagberg JM, Dalsky GP, Holloszy JO. Muscle triglyceride utilization during exercise: effect of training. J Appl Physiol 1986; 60: $562-7$

71. Issekutz B, Bortz WM, Miller HI, Paul P. Turnover rate of plasma FFA in humans and in dogs. Metabolism 1967; 16: $1001-9$

72. Issekutz B, Miller HI, Paul P, Rodahl K. Source of fat in exercising dogs. Am J Physiol 1964; 207: $583-9$

73. Issekutz B, Shaw WA, Issekutz TB. Effect of lactate on FFA and glycerol turnover in resting and exercising dogs. J Appl Physiol 1975; 39: 349-53

74. Jansson E. Diet and muscle metabolism in man. Acta Physiol Scand 1980; 487: 1-24

75. Jansson E, Kaijser L. Substrate utilization and enzymes in skeletal muscle of extremely endurance-trained men. J Appl Physiol 1987; 62: $999-1005$

76. Jones PJH, Pencharz PB, Clandinin MT, Whole body oxidation of dietary fatty acids: implications for energy utilization. Am J Clin Nutr 1985; 42: $769-77$

77. Kiens B, Essen-Gustavsson B, Christensen NJ, Saltin B. Skeletal muscle substrate utilization during submaximal exercise in man: effect of endurance training. J Physiol 1993; 469: 45978

78. Kiens B, Essen-Gustavsson B, Gad P, Lithell H. Lipoprotein lipase activity and intramuscular triglyceride stores after longterm high-fat and high-carbohydrate diets in physically trained men. Clin Physiol 1987; 7: 1-9

79. Kiens B, Lithell H. Lipoprotein metabolism influenced by training induced changes in human skeletal muscle. ] Clin Invest $1989 ; 83: 558-64$

80. Krogh $A$, Lindhard J. The relative value of fat and carbohydrate as sources of muscular energy. Bioch J 1920; 14: 290-363

81. Ladu MJ. Regulation of lipoprotein lipase in muscle and adipose tissue during exercise. J Appl Physiol 1991; 71: 404-9

82. Leyton J, Drury PJ, Crawford MA. Differential oxidation of saturated and unsaturated fatty acids in vivo in the rat. $\mathrm{Br} J$ Nutr 1987; 57: 383-93

83. Madsen J, Bülow J, Nielsen NE. Inhibition of FFA mobilization by arterial free fatty acid concentration. Acta Physiol Scand 1986; $127: 161-6$

84. Martin III WH, Dalsky GP, Hurley BF, Matthews DE, Bier DM, Hagberg JM, Rogers MA, King DS, Holloszy JO. Effect of endurance training on plasma free fatty acid turnover and oxidation during exercise. Am J Physiol 1993; 265: E708 -E714

85. McGarry JD, Foster DW. Regulation of hepatic fatty acid oxidation and ketone body production. Ann Rev Biochem 1980; 49: $395-420$

86. McGarry JD, Mills SE, Long CS, Foster DW, Observations on the affinity for carnitine, and malonyl-CoA sensitivity, of carnitine palmitoyl transferase I in animal and human tissues. Bioch J $1983 ; 214: 21-8$

87. McGarry JD, Stark MJ, Foster DW. Hepatic Malonyl-CoA levels of fed, fasted and diabetic rats as measured using simple radioisotopic assay. J Biol Chem 1978; 253: $8291-3$

88. McGilvery. The use of fuels for muscular work. Metabolic adaptation to prolonged physical exercise. Basel: Birkhauser Verlag, 1975: 12-30

89. Metges CC, Wolfram G. Medium- and long-chain triglycerides labelled with ${ }^{13} \mathrm{C}$ : A comparison of oxidation after oral or parenteral administration in humans. J Nutr 1991; $121: 31-6$

90. Miller WC, Bryce R, Conlee RK. Adaptation to a highfat diet that increase exercise endurance in male rats. J Appl Physiol 1984; $56: 78-83$

91. Murray R, Eddy DE, Paul GL, Seifert JG, Halaby GA. Physiological responses to glycerol ingestion during exercise. J Appl Physiol 1991; $71: 144-9$
92. Newsholme EA, Leech AR. Biochemistry for the medical sciences. Chichester: John Wiley \& Sons, 1990

93. Numa S. Fatty acid metabolism and its regulation. Amsterdam: Elsevier, 1984

94. Oberholzer $\mathrm{F}$, Claassen $\mathrm{H}$, Moesch $\mathrm{H}$, Howald $\mathrm{H}$. Ultrastrukturelle, biochemische und energetische Analyse einer extremen Dauerleistung (100 km Lauf). Schweiz Z Sportmed 1976 ; 24: $71-98$

95. Olsson $A G$, Eklund B, Kaijser $L$, Carlson LA. Extraction of endogenous plasma triglycerides by the working human forearm muscle in the fasting state. Scand J Clin Lab Invest 1975; 35 : $231-6$

96. Oscai LB, Essig DA, Palmer WK. Lipase regulation of muscle triglyceride hydrolysis. J Appl Physiol 1990; 69: 1571-7

97. Paul P. Effects of long lasting physical exercise and training on lipid metabolism. Metabolic adaptation to prolonged physica! exercise. Basel: Birkhauser Verlag, 1975: 156 - 93

98. Pearce FJ, Connett RJ. Effect of lactate and palmitate on substrate utilization of isolated rat soleus. Am J Physiol 1980; 238: $C 149-59$

99. Potter BJ, Sorrentino D, Berk PD. Mechanisms of cellular uptake of free fatty acids. Ann Rev Nutr 1989; 9:253-70

100. Reitman J, Baldwin KM, Holloszy JO. Intramuscular triglyceride utilisation by red, white and intermediate skeletal muscle and heart during exhaustive exercise. Proc soc Exp Biol Med 1973; 142: $628-31$

101. Richieri GV, Anel A, Kleinfeld AM. Interactions of long-chain fatty acids and albumin: determination of free fatty acid levels using the fluorescent probe (ADIFAB). Biochemistry 1993; 32: $7574-81$

102. Richieri GV, Kleinfeld AM. Unbound free fatty acid levels in human serum. J Lipid Res 1995; 36: 229 - 40

103. Richter EA. Interaction of fuels in muscle metabolism during exercise. In: Y. Sato et al. (eds). Integration of Medical and Sports Sciences. Basel, Karger (1992): 349-55

104. Robinson J. Newsholme EA. Glycerol kinase activity in rat heart and adipose tissue. Bioch J 1967; 104: $2 C-4 C$

105. Romijn JA, Coyle EF, Sidossis LS, Gastaldelli A, Horowitz JF, Endert E, Wolfe RR. Regulation of endogenous fat and carbohydrate metabolism in relation to exercise intensity. Am J Physiol 1993; 265: E380-E391

106. Saggerson ED, Carpenter CA. Carnitine palmitoyltransferase and carnitine octanoyltransferase activities in liver, kidney cortex, adipocyte, lactating mammary gland, skeletal muscle and heart. FEBS letter 1981; 129: 229-32

107. Sahlin K, Broberg S. Tricarboxylic acid cycle intermediates in human muscle during prolonged exercise. Am J Physiol 1990; 259: C834-C841

108. Saltin B, Astrand P-O. Free fatty acids and exercise. Am J Clin Nutr 1993; 57: 752S-758S

109. Saltin B, Golinick PD. Skeletal muscle adaptability: significance for metabolism and performance. In: Handbook of physiology. Baltimore, Williams and Wilkins, 1983: 555-661

110. Schaffer JE, Lodish HF. Expression cloning and characterization of a novel adipocyte long chain fatty acid transport protein. Cell 1994; 79: 427 - -36

111. Shaw WAS, Issekutz TB, Issekutz B. Interrelationship of FFA and glycerol turnovers in resting and exercising dogs. J Appl Physiol 1975; 39: 30-60

112. Sorrentino D, Stump D, Potter BJ, Robinson RB, White R, Kiang C-L, Berk PD. Oleate uptake by cardiac myocytes is carrier mediated and involves a $40-\mathrm{kD}$ plasma membrane fatty acid binding protein similar to that in liver, adipose tissue and gut. J Clin Invest 1988; 82: 928-35

113. Spector AA. Fatty acid binding to plasma albumin. J Lipid Res 1975; $16: 165-79$ 
114. Spencer MK, Yan Z, Katz A. Carbohydrate supplementation attenuates IMP accumulation in human muscle during prolonged exercise. Am J Physiol 1991; 261: C71 - C76

115. Spriet LL, Heigenhauser JF, Jones NL. Endogenous triacylglycerol utilization by rat skeletal muscle during tetanic stimulation. J Appl Physiol 1986; 60: 410-5

116. Stankiewicz-Choroszucha B, Gorski J. Effect of beta-adrenergic blockade on intramuscular triglyceride utilization during exercise. Experientia 1978; 34: 357-8

117. Stankiewicz-Choroszucha B, Gorski J. Effect of decreased availability of substrates on intramuscular triglyceride utilization during exercise. Eur ] Appl Physiol 1978; 40:27-35

118. Stremmel W, Strohmeyer G, Berk PD. Hepatocellular uptake of oleate is energy dependent, sodium linked, and inhibited by an antibody to a hepatocyte plasma membrane fatty acid binding protein. Proc Natl Acad Sci USA 1986; 83: 3584-8

119. Strohfeldt $P$, Heugel $C$. Characterisation of triglyceride lipase activities in rat skeletal muscle. Biochem Biophys Res Commun 1984; $121: 87-94$

120. Stumpf DA, Parker WD, Angelini C. Carnitine deficiency, organic acidemias, and Reye's syndrome. Neurology 1985; 35: $1041-5$

121. Taskinen M-R, Nikkilä EA, Rehunen $S$, Gordin A. Effect of vigourous exercise on lipoprotein lipase activity of adipose tissue and skeletal muscle in physically active men. Artery 1980; 6: 471-83

122. Terjung RL, Budohoski L, Nazar K, Kobryn A, Kaciuba-Uscilko. Chylomicron triglyceride metabolism in resting and exercising dogs. J Appl Physiol 1982; 52: 815-20

123. Turcotte LP. Hespel PJ, Graham TE, Richter EA. Impaired plasma FFA oxidation imposed by extreme $\mathrm{CHO}$ deficiency in contracting rat skeletal muscle. J Appl Physiol 1994; 77: 517-25

124. Turcotte LP, Kiens B, Richter EA. Saturation kinetics of palmitate uptake in perfused skeletal muscle. FEBS 1991; 279: $327-9$

125. Van der Vusse GJ, Glatz JFC, Stam HCG, Reneman RS. Fatty acid homeostasis in the normoxic and ischemic heart. Physiol Rev 1992; 72: $881-940$

126. Van der Vusse G], Reneman RS. Lipid metabolism in muscle. Handbook of Physiology, section 12: Exercise: Regulation and integration of multiple systems. New York: Oxford Press, 1996: $952-94$

127. Van Hall G. Ammino acids, ammonia and exercise in man. Maastricht: Maastricht University, 1996

128. Van Hall G, van der Vusse GJ, Soderlund K, Wagenmakers AJ. Deamination of amino acids as a source for ammonia production in human skeletal muscle during prolonged exercise. J Physiol 1995; 489: 251-61

129. van Nieuwenhoven FA, van der Vusse GJ, Glatz JFC. Membrane-associated and cytoplasmic fatty acid-binding proteins. Lipids 1996; 31: S223-S227

130. Vork MM, Glatz JFC, Surtel DAM, Knubben H, Van der Vusse JM and $G$. A sandwich enzyme linked immunosorbent assay for the determination of rat heart fatty acid binding protein using the straptavidin-biotin system. Application to tissue and effluent samples from normoxic rat heart perfusion. Biochim Biophys Acta 1991; 1075: 199-205

131. Wagenmakers AJM, Beckers EJ, Brouns F, Kuipers H, Soeters PB, van der Vusse GJ, Saris WHM. Carbohydrate supplementation, glycogen depletion, and amino acid metabolism during exercise. Am J Physiol 1990: 260

132. Wagenmakers AJM, Coakley JH, Edwards HT. Metabolism of branched chain amino acids and ammonia during exercise: clues from McArdle's disease. Int J Sports Med 1990; 11: S101-S113
133. Wahrenberg $H$, Engfeldt $P$, Bolinder J, Arner P. Acute adaptation in adrenergic control of lipolysis during physical exercise in humans. Am J Physiol 1987; 253: E383-E390

134. Walker M, Cooper BG, Elliott C, Reed JW, Orskov H, Alberti KGMM. Role of non-esterified fatty acids during and after exercise. Clin Sci 1991; 81:319-25

135. Wendling PS, Peters SJ, Heigenhauser GJF, Spriet LL. Variability of triacylglycerol content in human skeletal muscle biopsy samples. J Appl Physiol 1996; 81: 1150-1155

136. Williams RS, Caron MG, Daniel K. Skeletal muscle beta-adrenergic receptors: variations due to fiber type and training. Am J Physiol 1984; 246: E160 - E167

137. Williamson JR. Metabolic effects of epinephrine in the isolated, perfused rat heart. J Biol Chem 1964; 239: 2721 -9

138. Winder WW, Arogyasami J, Barton RJ, Elayan IM, Vehrs PR. Muscle malonyl-CoA decreases during exercise. J Appl Physiol 1989; 67: 2230-3

139. Winder WW, Arogyasami J, Elayan IM, Cartmill D. Time course of exercise-induced decline in malonyl-CoA in different muscle types. Am J Physiol 1990; 259: E266-271

140. Winder WW, Braiden RW, Cartmill DC, Hutber CA, Jones JP. EFfect of adrenomedullation on decline in musle malonyl- $\mathrm{COA}$ during exercise. J Appl Physiol 1993; 74: 2548-51

141. Wolfe RR. Radioactive and stable isotope tracers in biomedicine. New York: Wiley-Liss. 1992

142. Wolfe RR, Klein S, Carraro F, Weber J-M. Role of triglyceridefatty acid cycle in controlling fat metabolism in humans during and after exercise. Am J Physiol 1990; 258: E382-E389

143. Wolfe RR, Peters EJ, Klein S, Holland OB, Rosenblatt J, Gary H. Effect of short-term fasting on lipolytic responsiveness in normal and obese human subjects. Am J Physiol 1987; 252: E189-E196

144. Young DR, Shapira J, Forrest R, Adachi RR, Lim R, Pelligia R, Model for evaluation of fatty acid metabolism during prolonged exercise. J Appl Physiol 1967; 23: 716-25

145. Zuntz N. Über die Rolle des Zuckers im thierischen Stoffwechsel. Arch Physiol 1896: 538-77

146. Zuntz N. Über die Bedeutung der verschiedenen Nährstoffe als Erzeuger der Muskelkraft. Pfluglers Arch 1901; 83: 557-71

\section{Corresponding Author:}

Asker Jeukendrup, Ph.D.

Department of Human Biology

Maastricht University

P.O. Box 616

6200 MD Maastricht

The Netherlands 